\section{Aluminum Stress Affects Growth and Physiological Characteristics in Oil Tea}

\author{
Liyuan Huang, Jun Yuan, Hui Wang, and Xiaofeng $\operatorname{Tan}^{1}$
}

Key Laboratory of Non-Wood Forest Product of State Forestry Administration, The Key Laboratory of Cultivation and Protection for Non-wood Forest Trees, Ministry of Education, Central South University of Forestry and Technology, Changsha 410004, China

\section{Genhua Niu ${ }^{1}$ \\ Texas A\&M AgriLife Research Center at El Paso, Texas A\&M University System, 1380 A\&M Circle, El Paso, TX 79927}

Additional index words. Camellia oleifera, root morphology, photosynthetic characteristics, antioxidative enzymes, cell ultrastructure

\begin{abstract}
High concentration of aluminum ion $\left(\mathrm{Al}^{3+}\right)$ in acidic soil often negatively affects plant growth. To deepen understanding of the mechanisms of physiological response to Aluminum (Al) toxicity, changes in physiology and cell ultrastructure of oil tea (Camellia oleifera) were investigated under different $\mathrm{Al}$ levels. Oil tea plants were grown in pots filled with sand and treated with $\mathrm{Al}$ at $0,0.5,1.25,2.0$, or $4.0 \mathrm{~mm}$. Results showed that Al at 0.5-2.0 mu improved plant growth, whereas Al at $4.0 \mathrm{~mm}$ inhibited root growth and damaged cell ultrastructure. Net photosynthetic rate $\left(P_{n}\right)$, stomatal conductance $\left(g_{s}\right)$, transpiration rate $\left(T_{r}\right)$, and photochemical efficiency increased as Al concentration increased from 0 to $2.0 \mathrm{~mm}$; however, all parameters mentioned previously decreased at 4.0 mM. The activities of superoxide dismutase (SOD), peroxidase (POD), and catalase (CAT) in leaves treated with $2.0 \mathrm{~mm}$ Al reached the maximum, which were $29 \%, 63 \%$, and $28 \%$ higher than that of control. When $\mathrm{Al}$ was $\leq 2.0 \mathrm{~mm}$, the content of soluble sugar and soluble protein increased with increasing Al concentration. These results may indicate that oil tea adapted to Al stress through osmotic adjustment and through increasing antioxidant enzyme system. In summary, $\mathrm{Al}$ at low concentration $(0.5-2.0 \mathrm{~mm})$ improved growth and physiological performance, whereas $4.0 \mathrm{~mm}$ negatively impacted performance of oil tea.
\end{abstract}

$\mathrm{Al}$ is one of the most abundant metal elements in the earth's crust (Pilon-Smits et al., 2009). Its main forms presenting in soil are Al oxides and aluminosilicates. These forms of Al are usually unavailable for any toxic reactions in plants (Mukhopadyay et al., 2012). However, when soil $\mathrm{pH}$ decreases $(\mathrm{pH}<5.0)$, Al solubilizes into mobile ionic forms (such as $\mathrm{Al}^{3+}$ ) (Kochian et al., 2004). $\mathrm{Al}^{3+}$ is considered to be a major limiting factor to plant growth in acid soils (Horst et al., 2010). In China, acid soil covering an area of 0.203 million $\mathrm{km}^{2}$, consisting of $\approx 21 \%$ of the total arable land area (Qian et al., 2014). In recent years, the acid soil area was increased by increasing commercial ammonia/ammonium fertilizers application (Zhang and Raun, 2006). Therefore, Al toxicity concern is widespread and tremendous attention has been paid to exploring and understanding its resistance mechanism.

The initial and most dramatic symptom of Al toxicity is the inhibition of root growth

Received for publication 6 July 2017. Accepted for publication 26 Sept. 2017.

This study was supported by National Science Foundation of China (No.31400582) and Forestry Industry Research Special Funds for Public Welfare Projects (No.201404702-1).

${ }^{1}$ Corresponding authors. E-mail: tanxiaofengcm@ 126.com or gniu@ag.tamu.edu. and alteration of root morphology (Sivaguru and Horst, 1998). Within $40 \mathrm{~h}$ of hydroponics, the inhibition of root growth in Zea mays induced by $\mathrm{Al}(50 \mathrm{~mm})$ could be measured (Ryan et al., 1993). Previous studies found that $\mathrm{Al}(400 \mu \mathrm{M})$ could inhibit the root growth by decreasing the root volume, number of lateral roots, and activity in Triticum aesti2005; Zakir Hossain et al., 2006). Because of the inhibition of root growth in T. aestivum, water and nutrient uptake were inhibited (Vitorello et al., 2005). Another primary effect of Al toxicity is the excessive accumulation of reactive oxygen species (ROS), such as the hydroxyl radical $\left(\mathrm{OH}^{-}\right)$, hydrogen peroxide $\left(\mathrm{H}_{2} \mathrm{O}_{2}\right)$, and the superoxide anion radical $\left(\mathrm{O}_{2}^{-}\right)$(Bartels and Sunkar, 2005), which may break the balance between generation and scavenging of the ROS. To detoxify Al-induced ROS, plants employ enzymatic antioxidants, such as POD, SOD, and CAT (Boscolo et al., 2003; InostrozaBlancheteau et al., 2012). Al stress (0.4 mM) can destroy the ultrastructure of root cell in Dimocarpus longan and T. aestivum plants (Li et al., 2006). Physical changes, including increased vacuole size, destroyed nuclei and translocation of the amyloplasts in close proximity were observed in soybean that were grown under microgravity conditions (Klymchuk et al., 2003). vum and Camellia sinensis (Ghanati et al.,
By contrast, however, some plants can grow well on acid soils and take up large amounts of Al from the soil in their shoots without showing any symptom of Al toxicity. For example, buckwheat leaves can accumulate as much as $10 \mathrm{~g} \cdot \mathrm{kg}^{-1} \mathrm{Al}$ in the leaves in 12 weeks (Shen et al., 2006). Al (0.5 mM)induced improvements of the root activity contributed to a growth enhancement in Melastoma (Watanabe et al., 2005). $\mathrm{P}_{\mathrm{n}}, \mathrm{T}_{\mathrm{r}}$, $g_{\mathrm{s}}$, and growth of $C$. sinensis were enhanced by $\mathrm{Al}$ at $15 \mu \mathrm{M}$ (Mukhopadyay et al., 2012). A similar beneficial effect of $\mathrm{Al}$ on plant growth was reported in Miconia albicans (Haridasan, 1988) and Pinus radiate (Huang and Bachelard, 1993).

Oil tea is a unique woody edible oil tree in China and is one of the four major woody edible oil crops in the world (Gao et al., 2015). The extracted camellia oil has several favorable characteristics, including high oleic acid content typically exceeding $80 \%$ with low saturated fats content, which are very healthy (Yang et al., 2016). Oil tea is mainly distributed in acid soil in southern China. It was found that mature leaves of oil tea accumulate more than $13.5 \mathrm{~g} \cdot \mathrm{kg}^{-1} \mathrm{Al}$, which is considered a typical Al hyperaccumulator (Zeng et al., 2011). Unlike tea and other plants, limited information is available for oil tea on its responses to abiotic stress, such as Al toxicity. Therefore, the objective of this study was to understand the physiological mechanisms relating to oil tea in response to Al stress. Specifically, the effect of Al stress on the growth, root activity, leaf photosynthesis, chlorophyll fluorescence parameters, osmoregulation substance, antioxidative enzymes, and cell ultrastructure of oil tea were investigated in a pot experiment.

\section{Materials and Methods}

Plant materials and treatments. This experiment was conducted in Central South University of Forestry and Technology (CSUFT) in Hunan (Changsha, China; lat. $28^{\circ} 8^{\prime} 14^{\prime \prime} \mathrm{N}$, long. $112^{\circ} 59^{\prime} 32^{\prime \prime} \mathrm{E}$ ). The 1year-old oil tea seedlings were cultured by grafting a shoot of C. oleifera 'Huajin' onto germinated hypocotyl of seeds collected from a widely cultivar $(C$. oleifera ' $\mathrm{XLC15}$ ') as a rootstock. The healthy and uniform seedlings were selected and transplanted to plastic pots $(10 \mathrm{~cm}$ diameter $\times 20 \mathrm{~cm}$ height $)$ containing $2 \mathrm{~kg}$ sand (average particle size: $0.5-$ $1.0 \mathrm{~mm}$ ), two plants per pot. The grafted plants were acclimatized for 6 months (from 5 Jan. to 30 June 2015) outdoor before the Al treatment. Plants were watered every day, while the nutrient solution was given every 3-4 d. The nutrient solution was modified Hoagland solution, which composed of macronutrients: $\mathrm{Ca}\left(\mathrm{NO}_{3}\right)_{2}, \mathrm{KNO}_{3}, \mathrm{NH}_{4} \mathrm{NO}_{3}$, $\mathrm{KH}_{2} \mathrm{PO}_{4}$, and $\mathrm{MgSO}_{4}$ at $6,5,1,1$, and $4.0 \mathrm{~mm}$, respectively, and micronutrients: $\mathrm{KI}, \mathrm{HBO}_{3}$, $\mathrm{MnSO}_{4}, \mathrm{ZnSO}_{4}, \mathrm{Na}_{2} \mathrm{MoO}_{4} \cdot 2 \mathrm{H}_{2} \mathrm{O}, \mathrm{CuSO}_{4}$, $\mathrm{CoCl}_{2}$, and Fe-EDTA at 5, 100, 147, 53, $103,0.15,0.19$, and $50 \mu \mathrm{M}$, respectively.

After an acclimatization period of 6 months, $\mathrm{Al}$ was added to the nutrient solution 
and was supplied in the form of $\mathrm{AlCl}_{3}$ in concentrations of 0 (control), $0.5,1.25,2$, and $4.0 \mathrm{~mm}$ for $90 \mathrm{~d}$ (from 2 July to 30 Sept. 2015). The nutrient solution was adjusted to $\mathrm{pH} 4.2 \times 1 \mathrm{~m} \mathrm{HCl}$ or $\mathrm{NaOH}$. The seedlings were irrigated with 300 of $\mathrm{mL}$ nutrient solution
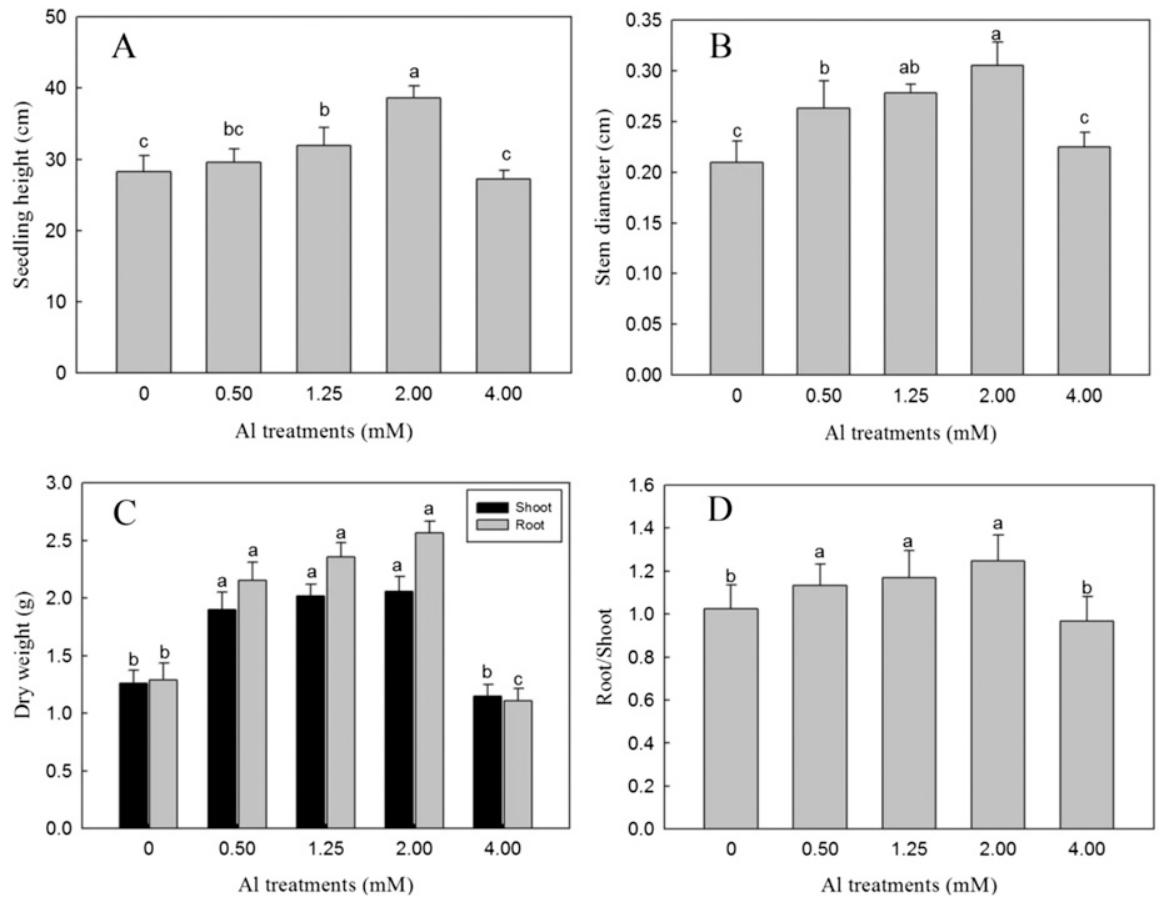

Fig. 1. Seedling height (A), stem diameter (B), dry weight (C), and root to shoot ratio (D) of oil tea (Camellia oleifera) as affected by aluminum. Vertical bars indicate standard errors. Different letters on the top of bars indicate significant difference at $P<0.05$ by least significant difference test.
20 pots (two plants per pot) per treatment. During the experimental period, the average temperature was 20 to $23{ }^{\circ} \mathrm{C}$ at night, 24 to $28{ }^{\circ} \mathrm{C}$ during the day, and relative humidity was $60 \%$ to $80 \%$.

Measurement of gas exchange and chlorophyll fluorescence parameters. The $\mathrm{P}_{\mathrm{n}}, g_{\mathrm{s}}$, intercellular $\mathrm{CO}_{2}$ concentration $\left(\mathrm{C}_{\mathrm{i}}\right)$, and $T_{r}$ were measured using the third fully expanded mature leaves (one leaf per plant; five plants per replicate). The measurements were taken at 9:00-10:00 on a clear day in the last week of the experiment, using a Li-6400 portable photosynthesis analyzer (Lincoln, NE). The environmental conditions of the leaf chamber were controlled at $P P F$ density at $1600 \mu \mathrm{mol} \cdot \mathrm{m}^{-2} \cdot \mathrm{s}^{-1}$, temperature at $27^{\circ} \mathrm{C}$, and $\mathrm{CO}_{2}$ concentration at $400 \mu \mathrm{mol} \cdot \mathrm{mol}^{-1}$.

Chlorophyll Fluorescence parameters were measured using LI-6400-40LCF (LICOR, Lincoln, NE). Leaves were darkadapted for $30 \mathrm{~min}$ before the fluorescence measurements. The minimal $\mathrm{Chl}$ fluorescence $\left(\mathrm{F}_{0}\right)$ level was measured after applying a far-red pulse for $6 \mathrm{~s}$, and the maximal fluorescence $\left(\mathrm{F}_{\mathrm{m}}\right)$ was registered after applying a $0.8 \mathrm{~s}$ saturating flash. The photochemical efficiency $\left(\mathrm{F}_{\mathrm{v}} / \mathrm{F}_{\mathrm{m}}\right)$ was expressed as: $\mathrm{F}_{\mathrm{v}} / \mathrm{F}_{\mathrm{m}}=\left(\mathrm{F}_{\mathrm{m}}-\mathrm{F}_{0}\right) / \mathrm{F}_{\mathrm{m}}$ (Genty et al., 1989).

Measurement of plant growth. At the end of the experiment, five pots per treatment were harvested to determine plant growth. The remaining plant materials were used for physiological and biochemical analysis, with three replicates (three pots). The plant was washed with distilled water, then the
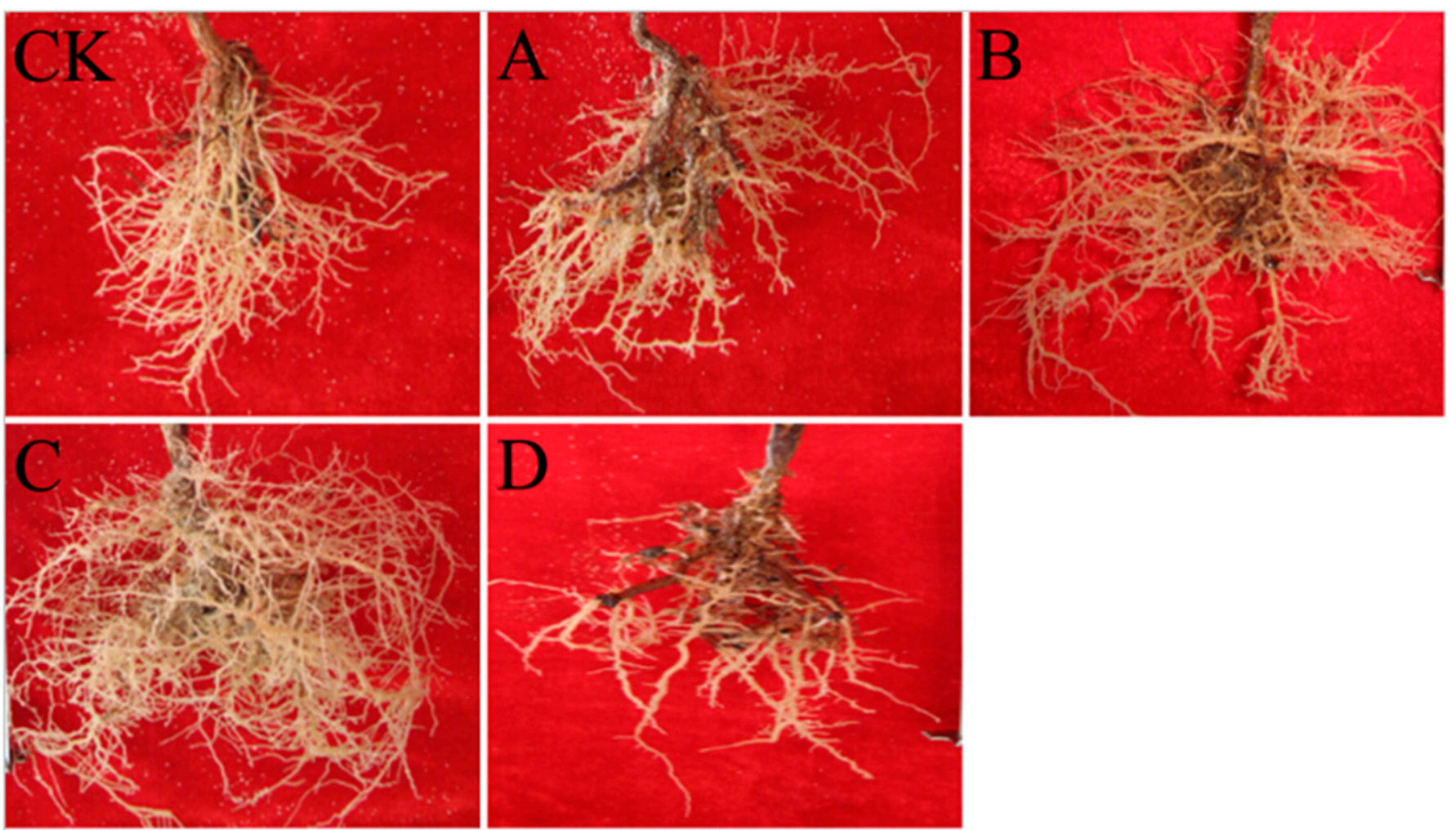

Fig. 2. The root growth of oil tea grown in pots treated with aluminum for $90 \mathrm{~d}$ at various concentrations: $0(\mathbf{C K}), 0.5 \mathrm{~mm}(\mathbf{A}), 1.25 \mathrm{~mm}(\mathbf{B}), 2.0 \mathrm{~mm}(\mathbf{C})$, or $4.0 \mathrm{~mm}(\mathbf{D})$. 
stem diameter and plant height were measured. Plant roots and shoots were separated and dried in an oven at $65^{\circ} \mathrm{C}$ for $48 \mathrm{~h}$, and dry weights were recorded.

Assay of root activity. The root activity was assayed according to $\mathrm{Yu}$ et al. (2011). The root tips (4-6 mm) were homogenized

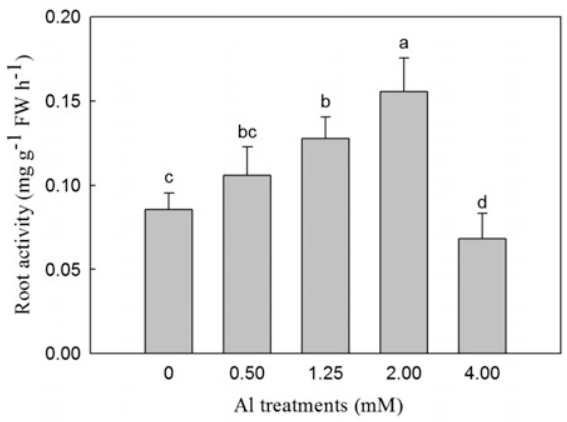

Fig. 3. Effects of aluminum stress on root activity of oil tea seedlings. Vertical bars indicate standard errors. Different letters on the top of bars indicate significant difference at $P<0.05$ by least significant difference test.
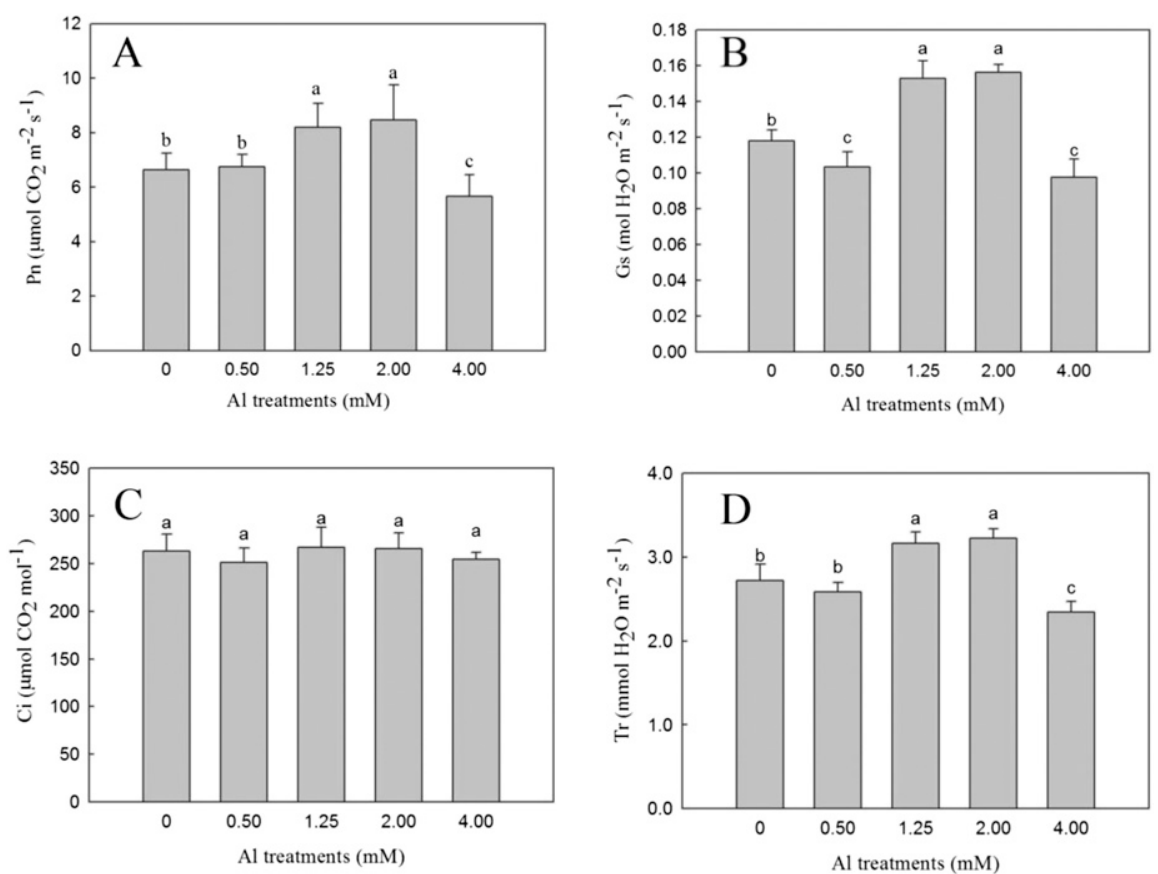

Fig. 4. Effects of aluminum (Al) stress on net photosynthetic rate $\left(\mathrm{P}_{\mathrm{n}}, \mathbf{A}\right)$, stomatal conductance $\left(g_{\mathrm{s}}, \mathbf{B}\right)$, intracellular $\mathrm{CO}_{2}$ concentration $\left(\mathrm{C}_{\mathrm{i}}, \mathbf{C}\right)$, transpiration rate $\left(\mathrm{T}_{\mathrm{r}}, \mathbf{D}\right)$ of oil tea seedlings grown in pots treated with $\mathrm{Al}$ at various concentrations. Vertical bars indicate standard error. Different letters on the top of bars indicate significant difference at $P<0.05$ by least significant difference test.

Table 1. Effect of aluminum (Al) stress on photochemical efficiency $\left(\mathrm{F}_{\mathrm{v}} / \mathrm{F}_{\mathrm{m}}\right)$, relative quantum efficiency of PSII photochemistry (ФPSII), and nonphotochemical quenching (NPQ) of oil tea grown in pots treated with $\mathrm{Al}$ at different concentrations.

\begin{tabular}{lccccc}
\hline & \multicolumn{5}{c}{ Al concn $(\mathrm{mm})$} \\
\cline { 2 - 6 } Chlorophyll fluorescence parameters & 0 & 0.50 & 1.25 & 2.00 & 4.00 \\
\hline $\mathrm{F}_{\mathrm{v}} / \mathrm{F}_{\mathrm{m}}$ & $0.806 \mathrm{~b}^{\mathrm{z}}$ & $0.810 \mathrm{a}$ & $0.811 \mathrm{a}$ & $0.813 \mathrm{a}$ & $0.801 \mathrm{c}$ \\
SPSII & $0.155 \mathrm{ab}$ & $0.160 \mathrm{a}$ & $0.161 \mathrm{a}$ & $0.145 \mathrm{~b}$ & $0.126 \mathrm{c}$ \\
NPQ & $2.948 \mathrm{~b}$ & $2.845 \mathrm{bc}$ & $2.757 \mathrm{c}$ & $3.229 \mathrm{a}$ & $2.369 \mathrm{~d}$ \\
\hline
\end{tabular}

${ }^{\mathrm{z}}$ Means within the same row followed by different letters are significantly different at $P<0.05$ by leas significant difference test.
Assay of soluble protein content. The soluble protein content in the leaf was assayed according to Bradford (1976) using bovine serum albumin as a standard. The fresh leaves from each Al treatment were washed with distilled water, dried with paper towel, and were ground in a mortar with $5 \mathrm{~mL}$ $0.5 \mathrm{~m}$ PBS. The homogenate was centrifuged at $5000 g_{\mathrm{n}}$ for $10 \mathrm{~min}$. Then, the supernatant absorbance was assayed at $625 \mathrm{~nm}$.

Assay of malondialdehyde (MDA) content. The MDA content in the leaf was assayed according to Jia et al. (2015). The fresh leaves were washed in distilled water, dried with paper towel, and were ground in an ice mortar with $5 \mathrm{~mL}$ of $0.5 \mathrm{M}$ PBS by grinding. The homogenate with $5 \mathrm{~mL}$ of $0.5 \%(\mathrm{w} / \mathrm{v}) 2$ thiobarbituric acid was prepared in 5\% trichloroacetic acid. The homogenate was placed in a boiling water bath for $10 \mathrm{~min}$, then quickly cooled in an ice bath and centrifuged at $3000 g_{n}$ for $15 \mathrm{~min}$. The supernatant liquor absorbance was assayed at 532,600 , and $450 \mathrm{~nm}$. The MDA content was calculated using the formula of $\left[6.452 \times\left(\mathrm{OD}_{532}-\mathrm{OD}_{600}\right)-\left(0.56 \times \mathrm{OD}_{450}\right)\right] \times$ plant tissue extraction compound (L)/the sample weight $(\mathrm{g})$

Assay of antioxidant enzyme activities. Leaves of oil tea were homogenized using a mortar and pestle in a medium containing $50 \mathrm{~mm}$ PBS $(\mathrm{pH}=7.0), 0.1 \mathrm{mmol} \cdot \mathrm{L}^{-1}$ EDTA$\mathrm{Na}_{2}$, and $1 \%(\mathrm{w} / \mathrm{v})$ Polyvinyl Pyrolidone. The homogenate was centrifuged at $15,000 g_{\mathrm{n}}$ for 15 min at $4{ }^{\circ} \mathrm{C}$.

Superoxide dismutase (SOD, EC1.15.1.1) activity was assayed according to Parida et al. (2004). The inhibition of the photochemical reduction of nitro blue tetrazolium (NBT) was spectrophotometrically measured at $560 \mathrm{~nm}$. One unit of SOD activity was defined as the amount of enzyme required to cause a $50 \%$ inhibition of the reduction of NBT. SOD activity was assayed at $560 \mathrm{~nm}$.

Peroxidase (POD, EC1.11.1.7) activity was assayed according to Farooq et al. (2013) with some modifications. The reaction mixture comprised $1 \mathrm{~mL}$ enzyme extract, $1 \mathrm{~mL} \mathrm{1 \% (v/v)} \mathrm{guaiacol,} 6.9 \mathrm{~mL}$ PBS, $1 \mathrm{~mL}$ $0.18 \%(\mathrm{v} / \mathrm{v}) \mathrm{H}_{2} \mathrm{O}_{2}$, then reaction at $25{ }^{\circ} \mathrm{C}$ for $15 \mathrm{~min}$, inhibited the reaction by $5 \%(\mathrm{v} / \mathrm{v})$ metaphosphoric acid. POD activity was assayed at $470 \mathrm{~nm}$.

Catalase (CAT, EC1.11.1.6) activity was assayed according to Parida et al. (2004). The reaction mixture comprised $0.1 \mathrm{~mL}$ enzyme extract, $1 \mathrm{~mL}$ PBS, $1.7 \mathrm{~mL}$ distilled water, and $0.2 \mathrm{~mL}$ of $0.2 \mathrm{M} \mathrm{H}_{2} \mathrm{O}_{2}$. The CAT activity assay was based on the spectrophotometric measurement of $\mathrm{H}_{2} \mathrm{O}_{2}$ absorbance decrease at $240 \mathrm{~nm}$.

Transmission electron microscope. After $90 \mathrm{~d}$ of Al treatment, young leaf pieces without veins (from 1 to $2 \mathrm{~cm}^{2}$ ) and root tips (from 0.2 to $0.5 \mathrm{~cm}$ ) were collected from randomly selected plants and then fixed overnight in $2.5 \%$ glutaraldehyde $(\mathrm{v} / \mathrm{v})$ in $0.1 \mathrm{M}$ PBS $(\mathrm{pH}=7.4)$ and cleaned three times with the same PBS (35 min each time). The samples were postfixed in $1 \%$ $\mathrm{OsO}_{4}$ for $12 \mathrm{~h}$, and then dehydrated in a graded series of acetone $(30 \%, 50 \%, 70 \%, 80 \%$, $90 \%, 95 \%$, and $100 \%$ ). After dehydration, the 
samples were embedded in Epon812 resin overnight and then heated at $70{ }^{\circ} \mathrm{C}$ for $9 \mathrm{~h}$. The ultrathin sections $(80 \mathrm{~nm})$ of samples were prepared and mounted on copper grids to be viewed under electron microscope (TEX-1230 EX; JEOL, Tokyo, Japan) at $60.0 \mathrm{kV}$ voltages.

Experimental design and statistical analysis. The experiment followed a completely randomized design with three (physiological and biochemical analyses) or five replicates (growth and morphological parameters). Data were analyzed by one-way analysis of variance using the statistical program SPSS 17.0 (SPSS, USA). Means were compared among the treatments using the least significant difference test at $5 \%$ probability level.

\section{Results}

Plant growth and development. The growth of oil tea was not adversely affected in the 0.5 to $2.0 \mathrm{~mm} \mathrm{Al}$ treatments (Fig. 1). Plants were taller in the $2.0 \mathrm{~mm}$, followed by those in the $1.25 \mathrm{~mm} \mathrm{Al}$ treatment. Stem diameter was greater in the $2.0 \mathrm{~mm}$ than those in $0,0.5$, and $4.0 \mathrm{~mm} \mathrm{Al} \mathrm{treatments.} \mathrm{No}$ differences were found in shoot and root dry weight and root/shoot ratio among $\mathrm{Al}$ concentrations of $0.5,1.25$, and $2.0 \mathrm{~mm}$. In the $4.0 \mathrm{~mm} \mathrm{Al}$ treatment, the root dry weight was significantly lower than that of other

Table 2. Effect of aluminum (Al) stress on soluble sugar, soluble protein, malondialdehyde (MDA), superoxide dismutase (SOD), peroxidase (POD), and catalase (CAT) of oil tea grown in pots treated with $\mathrm{Al}$ at different concentrations.

\begin{tabular}{lrrrrr}
\hline & \multicolumn{5}{c}{$\mathrm{Al} \operatorname{concn}(\mathrm{mm})$} \\
\cline { 2 - 6 } Index & \multicolumn{1}{c}{0} & \multicolumn{1}{c}{0.50} & 1.25 & \multicolumn{1}{c}{2.00} & 4.00 \\
\hline Soluble sugar $\left(\mathrm{mg} \cdot \mathrm{g}^{-1}\right)$ & $76.0 \mathrm{~b} \mathrm{c}^{\mathrm{z}}$ & $80.0 \mathrm{~b}$ & $88.1 \mathrm{~b}$ & $97.6 \mathrm{a}$ & $70.0 \mathrm{c}$ \\
Soluble protein $\left(\mathrm{mg} \cdot \mathrm{g}^{-1}\right)$ & $4.25 \mathrm{c}$ & $6.13 \mathrm{~b}$ & $6.70 \mathrm{ab}$ & $7.19 \mathrm{a}$ & $4.50 \mathrm{c}$ \\
MDA $\left(\mu \mathrm{mol} \cdot \mathrm{g}^{-1}\right)$ & $13.20 \mathrm{~b}$ & $12.00 \mathrm{c}$ & $13.11 \mathrm{~b}$ & $13.38 \mathrm{~b}$ & $15.35 \mathrm{a}$ \\
$\mathrm{SOD}$ activity $\left(\mathrm{U} \cdot \mathrm{g}^{-1} \mathrm{FW} \cdot \mathrm{min}^{-1}\right)$ & $121.34 \mathrm{c}$ & $130.09 \mathrm{~b}$ & $138.56 \mathrm{~b}$ & $149.21 \mathrm{a}$ & $111.86 \mathrm{~d}$ \\
$\mathrm{CAT}$ activity $\left(\mathrm{mg} \mathrm{H} \mathrm{H}_{2} \cdot \mathrm{g}^{-1} \mathrm{FW} \cdot \mathrm{min}^{-1}\right)$ & $78.10 \mathrm{~b}$ & $80.23 \mathrm{~b}$ & $93.24 \mathrm{a}$ & $99.75 \mathrm{a}$ & $70.17 \mathrm{c}$ \\
POD activity $\left(\mathrm{U} \cdot \mathrm{g}^{-1} \mathrm{FW} \cdot \mathrm{min}^{-1}\right)$ & $0.89 \mathrm{c}$ & $0.93 \mathrm{c}$ & $1.32 \mathrm{~b}$ & $1.45 \mathrm{a}$ & $0.80 \mathrm{c}$ \\
\hline
\end{tabular}

${ }_{\mathrm{z}}$ Means within the same row followed by different letters are significantly different at $P<0.05$ by least significant difference test.
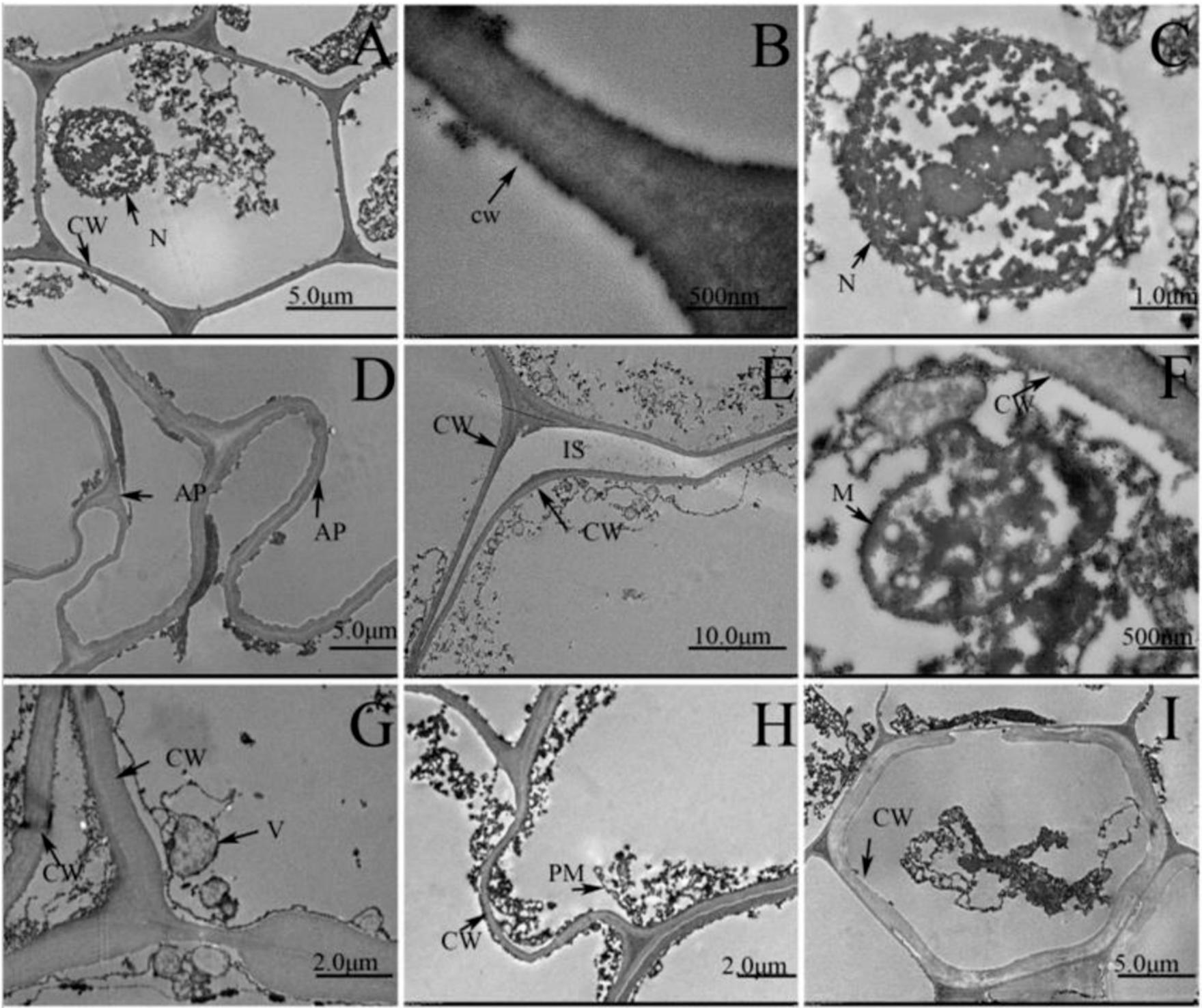

Fig. 5. Electron micrographs of oil tea root tip cell under aluminum (Al) stress. (A-C) The oil tea seedling without Al treatment showing intact structural configuration of root tip cells with a big nucleus. (D-F) The oil tea seedling with $2.0 \mathrm{~mm} \mathrm{Al}$ treatment showing slight changes in the root tips in comparison with control. The cell wall became protrusive, the intercellular spaces increased, and the mitochondria bulged outward. (G-I) The oil tea seedling with $4.0 \mathrm{~mm}$ $\mathrm{Al}$ treatment showing the vesicles around the root tip cell wall, the broken plasma membrane and the decreased cell inclusion. $\mathrm{CW}=\mathrm{cell}$ wall; $\mathrm{N}=$ nucleus; $\mathrm{AP}=$ amoeboid folds; $\mathrm{IS}=$ intercellular space; $\mathrm{M}=$ mitochondria; $\mathrm{V}=$ vesicles; $\mathrm{PM}=$ plasmalemma. 

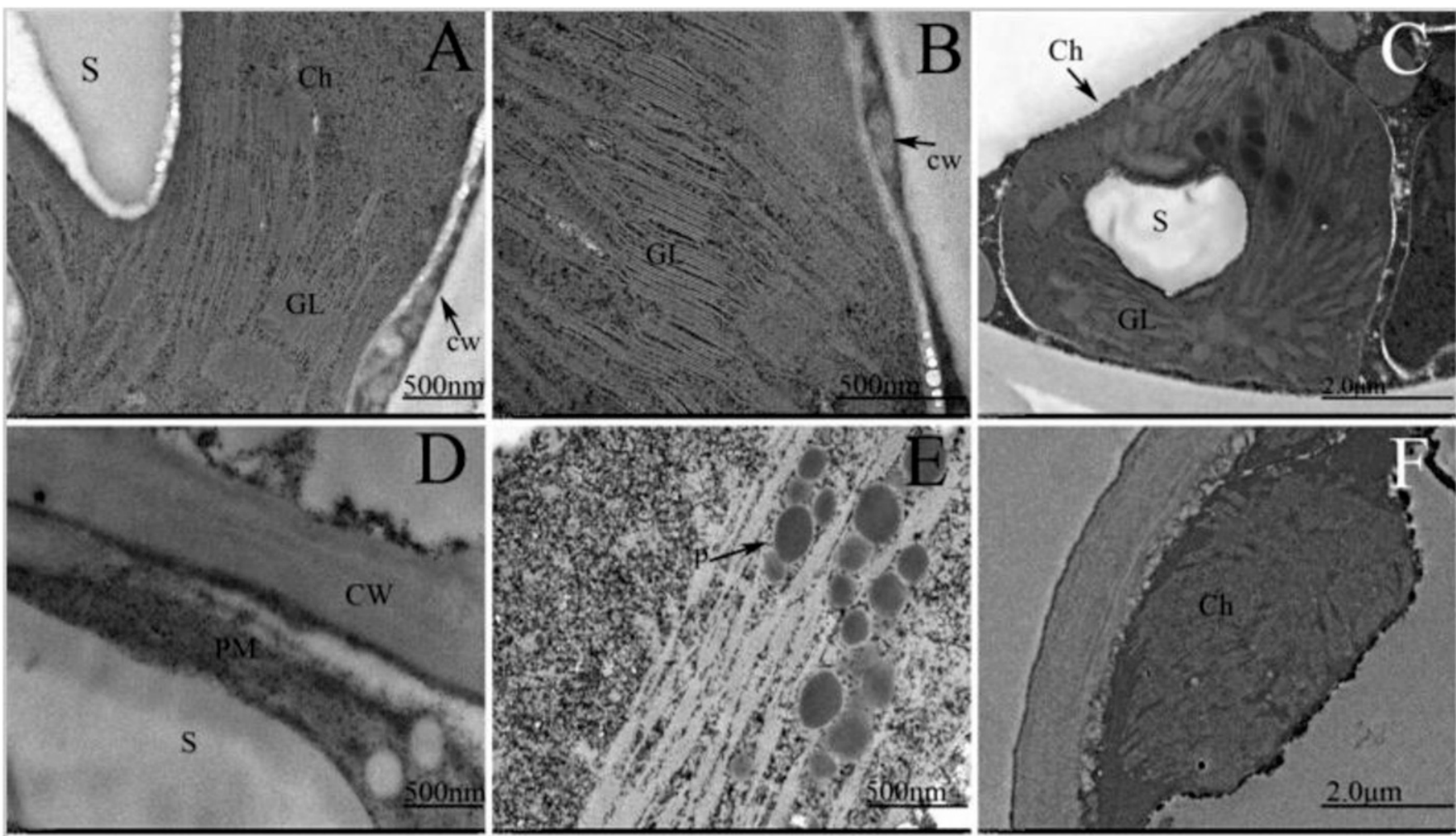

Fig. 6. Electron micrographs of oil tea leaf cell under aluminum (Al) stress. (A-C) The oil tea seedling without Al treatment showing the chloroplasts with a welldeveloped lamellar system and regularly arranged grana lamellar. The starch grains are present, whereas the plastoglobuli were not. (D-F) The oil tea seedling with $4.0 \mathrm{~mm} \mathrm{Al} \mathrm{treatment} \mathrm{showing} \mathrm{the} \mathrm{grana} \mathrm{lamellar} \mathrm{appear} \mathrm{to} \mathrm{expand} \mathrm{and} \mathrm{decreased,} \mathrm{whereas} \mathrm{the} \mathrm{number} \mathrm{of} \mathrm{plastoglobuli} \mathrm{was} \mathrm{increased.} \mathrm{The} \mathrm{starch} \mathrm{grains}$ decreased or even disappeared. There is no difference between control and $2.0 \mathrm{~mm} \mathrm{Al}$ treatments in ultrastructure of leaves, therefore these images are not presented. $\mathrm{Ch}=$ chloroplast; $\mathrm{GL}=$ grana lamella; $\mathrm{S}=$ starch grain; $\mathrm{CW}=$ cell wall; $\mathrm{PM}=$ plasmalemma; $\mathrm{P}=$ plastoglobuli.

treatments. The lateral roots were well developed at $2.0 \mathrm{~mm} \mathrm{Al} \mathrm{treatments} \mathrm{(Fig.} \mathrm{2C).}$ By contrast, growth of lateral roots were inhibited at $4.0 \mathrm{~mm} \mathrm{Al} \mathrm{treatments} \mathrm{with} \mathrm{shorter}$ and fewer lateral roots (Fig. 2D). There were no significant differences among $\mathrm{CK}$, A, and B (Fig. 2).

Root activity. The root activity was the greatest in the $2.0 \mathrm{~mm} \mathrm{Al}$ treatment $(82.3 \%$ increase compared with control), followed by those in the 0.5 and $1.25 \mathrm{~mm} \mathrm{Al}$ treatments (Fig. 3). No difference was found between control and $\mathrm{Al}$ at $0.5 \mathrm{~mm}$ concentration. In contrast to the control, $20 \%$ decline was noticed in the root activity in response to $4.0 \mathrm{~mm} \mathrm{Al}$.

Gas exchanges and chlorophyll fluorescence parameters. The $\mathrm{P}_{\mathrm{n}}, g_{\mathrm{s}}$, and $\mathrm{T}_{\mathrm{r}}$ were $23.4 \%$ to $27.3 \%, 29.6 \%$ to $32.6 \%$, and $16.3 \%$ to $18.5 \%$, respectively, higher at $\mathrm{Al}$ concentrations of 1.25 and $2.0 \mathrm{~mm}$ compared with the control (Fig. 4). No differences were found in $P_{n}$ and $\mathrm{T}_{\mathrm{r}}$ between the control and $\mathrm{Al}$ at $0.5 \mathrm{~mm}$ concentration and between $\mathrm{Al}$ at 1.25 and $2.0 \mathrm{~mm}$. Al at $4.0 \mathrm{~mm}$ significantly reduced $\mathrm{P}_{\mathrm{n}}$ by $14.8 \%, g_{s}$ by $17.1 \%$ and $\mathrm{T}_{\mathrm{r}}$ by $13.9 \%$ compared with their respective controls. No differences were found in $\mathrm{C}_{\mathrm{i}}$ among $\mathrm{Al}$ treatments.

Chlorophyll fluorescence parameters of oil tea were influenced by Al treatments (Table 1). $\mathrm{F}_{\mathrm{v}} / \mathrm{F}_{\mathrm{m}}$ at $\mathrm{Al}$ concentrations of 0.5 , 1.25 , and $2.0 \mathrm{~mm}$ was similar, which was slightly higher than that of the control, and $\mathrm{Al}$ at $4.0 \mathrm{~mm}$ resulted in the lowest $\mathrm{F}_{\mathrm{v}} / \mathrm{F}_{\mathrm{m}}$. However, all $\mathrm{F}_{\mathrm{v}} / \mathrm{F}_{\mathrm{m}}$ values were above 0.8 . No differences were found in relative quantum efficiency of PSII photochemistry (ФPSII) among Al concentration of 0.5 , $1.25 \mathrm{~mm}$, and the control. The nonphotochemical quenching (NPQ) was greatest in the $2.0 \mathrm{~mm}$, followed by those in the control and $0.5 \mathrm{~mm} \mathrm{Al}$ treatments. $\mathrm{Al}$ at $4.0 \mathrm{~mm}$ resulted in the lowest $\Phi P S I I$ and NPQ.

Osmoregulation substance and antioxidative enzymes. The content of soluble sugar was greatest in the $2.0 \mathrm{~mm} \mathrm{Al}$ treatment, $28.4 \%$ increase compared with control (Table 2). No differences were found between the control and $\mathrm{Al}$ at $0.5,1.25 \mathrm{~mm}$, and between control and $\mathrm{Al}$ at $4.0 \mathrm{~mm}$. The content of soluble protein was greater in $2.0 \mathrm{~mm}$ than those in control, 0.5 and $4.0 \mathrm{~mm} \mathrm{Al} \mathrm{treatments.} \mathrm{The}$ MDA content increased by $16.3 \%$ over the control in response to $4.0 \mathrm{~mm} \mathrm{Al}$ treatment. There were no differences among $0,1.25$, and $2.0 \mathrm{~mm}$ Al treatments, whereas MDA was lowest at $\mathrm{Al}$ of $0.5 \mathrm{~mm}$.

Al significantly altered the activities of antioxidant enzymes-SOD, POD, and CAT in oil tea leaves (Table 2). The activity of SOD was higher at $\mathrm{Al}$ of $2.0 \mathrm{~mm}$ and followed by those at $\mathrm{Al}$ concentration of 0.5 and $1.25 \mathrm{~mm}$, whereas $\mathrm{Al}$ at $4.0 \mathrm{~mm}$ resulted in the lowest SOD. Likewise, the activities of CAT were higher at $\mathrm{Al}$ of 1.25 and $2.0 \mathrm{~mm}$ treatments, followed by control and $\mathrm{Al}$ at $0.5 \mathrm{~mm}$, whereas $\mathrm{Al}$ at $4.0 \mathrm{~mm}$ had the lowest CAT.
The activities of POD were greatest in $2.0 \mathrm{~mm}$ Al treatment with a $62.9 \%$ increase compared with control, followed by those in the $1.25 \mathrm{~mm} \mathrm{Al}$ treatment. No differences were found in POD among control, $\mathrm{Al}$ at 0.5 and $4.0 \mathrm{~mm}$ concentrations.

Root tip and leaf ultrastructure. Transmission electron micrographs of the root tip cells are shown in Fig. 5. In the control (Fig. 5A-C), the configuration of the root tip cells was well structured and the ultrastructural characteristics were normal. The nucleus was visible with well-developed nuclear membrane and nucleolus. At $\mathrm{Al}$ of $2.0 \mathrm{~mm}$ (Fig. 5D-F), there were slight changes in the root tips in comparison with control. Generally, the cell wall became protrusive, the intercellular spaces increased, and the mitochondria bulged outward. The main alteration observed was the root tip appearance in $4.0 \mathrm{~mm} \mathrm{Al}$ concentration (Fig. 5G-I) with disrupted cell wall. There were some vesicles around the cell wall and the plasma membrane was broken. The cell inclusions were decreased. The phenomenon of the plasmolysis slightly appears in the root tip cell.

In the control (Fig. 6A-C), the configuration of the chloroplast was well structured. There were oblong chloroplasts having regular arrangements of thylakoid membranes. The chloroplasts with a well-developed lamellar system and the grana lamellar arranged regularly. The starch grains could be observed, 
whereas the plastoglobuli were invisible. Al treatments adversely affected leaf mesophyll cellular structures as evident in the $4.0 \mathrm{~mm} \mathrm{Al}$ treatments (Fig. 6D-F). The grana lamellar in chloroplast appeared to expand, and the structure was loose. Compared with the control, the structures of grana lamellar were decreased. The starch grains obviously decreased or even disappeared, whereas the number of plastoglobuli was increased.

\section{Discussion}

Al toxicity in plants occurs in acidic soils (Matsumoto, 2000). Cocker et al. (1998) showed that Al toxicity affected the growth and physiological parameters of T. aestivum. However, in this study, addition of $\mathrm{Al}$ at 1.25 and $2.0 \mathrm{~mm}$ to the nutrient solution did not inhibit growth of oil tea but instead stimulated growth. Kinraide (1993) reported that alleviation of $\mathrm{H}^{+}$production under acidic conditions by $\mathrm{Al}$ might be the reason behind increases in growth.

Root activity may reflect plant toxicity response to heavy metal (Islam et al., 2007) because roots are directly in contact with the contaminated environment, such as heavy metals. In this study, we found that $\mathrm{Al}$ at $\leq 2.0 \mathrm{~mm}$ could actually stimulate root activity, thus maintaining high respiration metabolism and strengthening the uptake of minerals and water. Similar results were reported in various plant species (Ghanati et al., 2005, Li et al., 2004). However, at Al concentration of $4.0 \mathrm{~mm}$, root activity decreased, indicating negative impact of $\mathrm{Al}$ on the activities of the root as well as the entire root system.

Photosynthesis is a highly regulated and integrated process in plants. The photosynthetic process is highly sensitive to environment stress (Sun et al., 2009). Previous studies have shown that Al toxicity affects photosynthesis in Citrus grandis (Jiang et al., 2009). Al toxicity reduced stomatal opening and thus reduced $g_{\mathrm{s}}$, resulting in decreased photosynthesis of Artemisia annua (Aftab et al., 2010). In the present study, oil tea reflected the similar phenomenon with regard to decreasing $\mathrm{P}_{\mathrm{n}}, g_{\mathrm{s}}$, and $\mathrm{T}_{\mathrm{r}}$ under $\mathrm{Al}$ (4.0 mM) treatment. But these parameters were significantly improved under $\mathrm{Al}$ of 1.25 and $2.0 \mathrm{~mm}$. These results confirmed that $\mathrm{Al}$ at appropriate concentrations stimulated growth and that toxicity occurred when $\mathrm{Al}$ was higher than threshold. $\mathrm{F}_{\mathrm{v}} / \mathrm{F}_{\mathrm{m}}$ values can be used as a nondestructive or noninvasive tool to determine the function of photosynthetic apparatus. In healthy leaves, $F_{v} / F_{m}$ is commonly close to 0.82 (Havaux, 1993). In the present study, $F_{v} / F_{m}$ values were close to 0.82 at $\mathrm{Al}$ concentration from 0.5 to $2.0 \mathrm{~mm}$. This indicated that the oil tea had strong photosynthetic acclimation under Al stress.

Plants generally face oxidative damage when exposed to Al and other metals (Kaya et al., 2009). Al treatment can result in peroxidation by triggering a greater production of ROS. To detoxify ROS caused by $\mathrm{Al}$ treatment, plants employ enzymatic antioxidants, primarily including SOD, POD, and CAT (Boscolo et al., 2003). In this study, the activity of SOD and POD were the highest at $\mathrm{Al}$ of $2.0 \mathrm{~mm}$. Veljovic-Jovanovic et al. (2006) showed that SODs together with PODs form the first line of antioxidant defense against ROS. In the SOD-POD system, SODs first degrade $\mathrm{O}_{2}^{-1}$ into $\mathrm{O}_{2}$ and $\mathrm{H}_{2} \mathrm{O}_{2}$, and the latter is then degraded by POD into $\mathrm{H}_{2} \mathrm{O}$ and $\mathrm{O}_{2}$ (Boscolo et al., 2003). Our experiment results revealed high CAT activity at $\mathrm{Al}$ concentration of 1.25 and $2.0 \mathrm{~mm}$. Similarly, CAT is a key enzyme in the scavenging of $\mathrm{H}_{2} \mathrm{O}_{2}$ to water and molecular oxygen via transfer of two electrons (Mukhopadyay et al., 2012). In accordance with earlier reports in tea plant (Ghanati et al., 2005, Li et al., 2011), our findings suggest that induced enzyme activities may also be involved in modulating the resistance of oil tea plants exposed to Al stress and exhibited stimulatory effect on growth. MDA concentration has been used as an indicator of lipid peroxidation as well as stress level (Chaoui et al., 1997). Excess ROS reacts with lipids, proteins, and nucleic acids resulting in the rise of MDA, causing severe damage to plant cells (Halliwell and Gutteridge, 1990). Our study showed that MDA was increased in leaves under Al of $4.0 \mathrm{~mm}$, indicating loss of membrane functions and induction of oxidative damage.

Excessive Al supply may affect the cellular structure. In our present study, plant root tip cells and mesophyll cell showed significant changes under Al treatments. The root tip cell wall became protrusive, and the intercellular spaces slightly increased in $2.0 \mathrm{~mm} \mathrm{Al}$ treatment, which might be caused by the $\mathrm{Al}$ accumulation. The changes in root tip cells prevented their normal physiological function from Al toxicity. The folds and protuberance increased the surface area and served as an adaptive strategy to provide physiological advantage for the enhanced transport of ions and water under stress (Kurkova et al., 2002). With the increase in $\mathrm{Al}$ concentration ( $\mathrm{Al}$ at $4.0 \mathrm{~mm})$, the vesicles around the root tip cell wall and plasma membrane were damaged. Similarly, in leaf ultrastructure, $\mathrm{Al}$ at $4.0 \mathrm{~mm}$ damaged the chloroplast, which resulted in a number of plastoglobuli, disappearance of starch grains, and decreased grana lamellar. Numerous plastoglobuli distributed in the stroma is usually considered a symptom of senescence because these globules were regarded as lipid droplets from thylakoid degradation (Esposito et al., 2012).

\section{Conclusion}

Based on the physiological, biochemical, and anatomical analyses, we conclude that application of moderate $\mathrm{Al}(\leq 2.0 \mathrm{~mm})$ enhanced the growth of oil tea seedlings. The increased osmoregulation substance and the formation of strong antioxidant enzyme system in oil tea helped maintain cell turgor and protected cells from Al toxicity. In addition, greater root activity may provide enhanced ability for oil tea in acquisition of nutrients with limited availability in acid soil, such as phosphorus. However, Al at $4.0 \mathrm{~mm}$ inhibited the root growth, damaged the cell ultrastructure, and decreased plant physiological activity.

\section{Literature Cited}

Aftab, T., M.M.A. Khan, M. Idrees, and M. Naeem. 2010. Effects of aluminum exposures on growth, photosynthetic efficiency, lipid peroxidation and artemisinin content of Artemisia aпnиa L. J. Phytol. 2:23-37.

Bartels, D. and R. Sunkar. 2005. Drought and salt tolerance in plants. Crit. Rev. Plant Sci. 24:23-58.

Boscolo, P.R.S., M. Menossi, and R.A. Jorge. 2003. Aluminum-induced oxidative stress in maize. Phytochemistry 62:181-189.

Bradford, M.M. 1976. A rapid and sensitive method for the quantitation of microgram quantities of protein utilizing the principle of protein-dye binding. Anal. Biochem. 72:248-254.

Chaoui, A., S. Mazhoudi, M.H. Ghorbal, and E. Ferjani. 1997. Cadmium and zinc induction of lipid peroxidation and effects on antioxidant enzyme activities in bean (Phaseolus vulgaris L.). Plant Sci. 127:139-147.

Cocker, K.M., D.E. Evans, and M.J. Hodson. 1998 The amelioration of aluminum toxicity by silicon in wheat (Triticum aestivum L.): Malate exudation as evidence for an in planta mechanism. Planta 204:318-323.

Esposito, S., S. Sorbo, B. Conte, and A. Basile. 2012. Effects of heavy metals on ultrastructure and HSP70s induction in the aquatic moss Leptodictyum riparium Hedw. Intl. J. Phytoremediation 14:443-455.

Farooq, M.A., S. Ali, A. Hameed, W. Ishaque, K. Mahmood, and Z. Iqbal. 2013. Alleviation of cadmium toxicity by silicon is related to elevated photosynthesis, antioxidant enzymes; suppressed cadmium uptake and oxidative stress in cotton. Ecotoxicol. Environ. Saf. 96:242-249.

Gao, C., D.Y. Yuan, B.F. Wang, Y. Yang, D.M. Liu, and Z.Q. Han. 2015. A cytological study of another and pollen development in Camellia oleifera. Genet. Mol. Res. 14:8755-8765.

Genty, B., J.M. Briantais, and N.R. Baker. 1989. The relationship between the quantum yield of photosynthetic electron transport and quenching of chlorophyll fluorescence. Biochim. Biophys. Acta 990:87-92.

Ghanati, F., A. Morita, and H. Yokota. 2005. Effects of aluminum on the growth of tea plant and activation of antioxidant system. Plant Soil 276:133-141.

Halliwell, B. and J.M.C. Gutteridge. 1990. Role of free radicals and catalytic metal ions in human disease: An overview. Methods Enzymol. 186:1-8.

Haridasan, M. 1988. Performance of Miconia albicans (SW.) Triana, an aluminum accumulating species, in acidic and calcareous soils. Commun. Soil Sci. Plan. 19:1091-1103.

Havaux, M. 1993. Rapid photosynthetic adaptation to heat stress triggered in potato leaves by moderately elevated temperatures. Plant Cell Environ. 16:461-467.

Horst, W.J., Y.X. Wang, and D. Eticha. 2010. The role of the root apoplast in aluminum induced inhibition of root elongation and in aluminum resistance of plants: A review. Ann. Bot. 106:185-197.

Huang, J. and E.P. Bachelard. 1993. Effects of aluminum on growth and cation uptake in seedlings of Eucalyptus mannifera and Pinus radiata. Plant Soil 149:121-127. 
Irigoyen, J.J., D.W. Einerich, and M. SánchezDíaz. 1992. Water-stress induced changes in concentrations of proline and total soluble sugars in nodulated alfalfa (Medicago sativa) plants. Physiol. Plant. 84:55-60.

Inostroza-Blancheteau, C., Z. Rengel, M. Alberdi, M.D.D.L. Mora, F. Aquea, P. Arce-Johnson, and M. Reyes-Díaz. 2012. Molecular and physiological strategies to increase aluminum resistance in plants. Mol. Biol. Rpt. 39:2069-2079.

Islam, E., X.E. Yang, T.Q. Li, D. Liu, X.F. Jin, and F.H. Meng. 2007. Effect of Pb toxicity on root morphology, physiology and ultrastructure in the two ecotypes of Elsholtzia argyi. J. Hazard. Mater. 147:806-816.

Jia, X., C.S. Sun, G.Y. Li, G.B. Li, and G.L. Chen. 2015. Effects of progressive drought stress on the physiology, antioxidative enzymes and secondary metabolites of Radix Astragali. Acta Physiol. Plant. 37:262.

Jiang, H.X., N. Tang, J.G. Zheng, Y. Li, and L.S. Chen. 2009. Phosphorus alleviates aluminuminduced inhibition of growth and photosynthesis in Citrus grandis seedlings. Physiol. Plant. 137:298-311.

Kaya, C., A.L. Tuna, O. Sonmez, F. Ince, and D. Higgs. 2009. Mitigation effects of silicon on maize plants grown at high zinc. J. Plant Nutr. 32:1788-1798.

Kinraide, T.B. 1993. Aluminum enhancement of plant growth in acid rooting media. A case of reciprocal alleviation of toxicity by two toxic cations. Physiol. Plant. 88:619-625.

Klymchuk, D.O., E.L. Kordyum, T.V. Vorobyova, D.K. Chapan, and C.S. Brown. 2003. Changes in vacuolation in the root apex cells of soybean seedling in microgravity. Adv. Space Res. 31:2283-2288.

Kochian, L.V., O.A. Hoekenga, and M.A. Pineros. 2004. How do crop plants tolerate acid soils? Mechanisms of aluminum tolerance and phosphorous efficiency. Annu. Rev. Plant Biol. 55:459-493.

Kurkova, E.B., N.A. Myasoedov, A.A. Kotov, L.M. Kotova, R.V. Luńkov, N.Z. Shamsutdinov, and Y. Balnokin. 2002. Specific structure of root cells of the salt-accumulating halophyte Suaeda altissima L. Dokl. Biol. Sci. 387:573576.

Li, C.L., H.M. Xu, J. Xu, X.Y. Chun, and D.J. Ni. 2011. Effects of aluminum on ultrastructure and antioxidant activity in leaves of tea plant. Acta Physiol. Plant. 33:973-978.

Li, C.S., P. Liu, G.D. Xu, W.B. He, and J. Zhu. 2004. Effect of acid-Al on the germination of soaked buckwheat seeds. J. Seed 23:9-11.

Li, C.S., P. Liu, G.D. Xu, and H.J. Lin. 2006. Ameliorating effects of exogenous organic acids on aluminum toxicity in buckwheat seedlings. J. Acta Agronomica Sinica 32:532539.

Matsumoto, H. 2000. Cell biology of aluminum toxicity and tolerance in higher plants. Intl. Rev. Cytol. 200:1-46.

Mukhopadyay, M., P. Bantawa, A. Das, B. Sarkar, B. Bera, P. Ghosh, and T.K. Mondal. 2012. Changes of growth, photosynthesis and alteration of leaf antioxidative defence system of tea [Camellia sinensis (L.) O. Kuntze] seedlings under aluminum stress. Biometals 25:1141-1154.

Parida, A.K., A.B. Das, and P. Mohanty. 2004. Defense potentials to $\mathrm{NaCl}$ in a mangrove, Bruguiera parviflora: Differential changes of isoforms of some antioxidative enzymes. J. Plant Physiol. 161:531-542.

Pilon-Smits, E.A., C.F. Quinn, W. Tapken, M Malagoli, and M. Schiavon. 2009. Physiological functions of beneficial elements. Curr. Opin. Plant Biol. 12:267-274.

Qian, P., R. Sun, B. Ail, R.A. Gill, L. Xu, and W.J. Zhou. 2014. Effects of hydrogen sulfide on growth, antioxidative capacity, and ultrastructural changes in oilseed rape seedlings under aluminum toxicity. J. Plant Growth Regulat. 33:526-538.

Ryan, P.R., J.M. Ditomaso, and L. Kochian. 1993. Aluminum toxicity in roots: An investigation of spatial sensitivity and the role of the root cap. J. Expt. Bot. 44:437-446.

Shen, R.F., R.F. Chen, and J.F. Ma. 2006. Buckwheat accumulates aluminum in leaves but not in seeds. Plant Soil 284(1):265-271.
Sivaguru, M. and W.J. Horst. 1998. The distal part of the transition zone is the most aluminumsensitive apical root zone of maize. Plant Physiol. 116:155-163.

Sun, C.X., H. Qi, J.J. Hao, L. Miao, J. Wang, Y. Wang, M. Liu, and L.J. Chen. 2009. Single leaves photosynthetic characteristics of two insect resistant transgenic cotton (Gossypium hirsutum L.) varieties in response to light. Photosynthetica 47:399-408.

Veljovic-Jovanovic, S., B. Kukavica, B. Stevanovic, and F. Navari-Izzo. 2006. Senescence and drought-related changes in peroxidase and superoxide dismutase isoforms in leaves of Ramonda serbica. J. Expt. Bot. 57:17591768

Vitorello, V.A., F.R. Capaldi, and V.A. Stefanuto. 2005. Recent advances in aluminum toxicity and resistance in higher plants. Braz. J. Plant Physiol. 17:129-143.

Watanabe, T., S. Jansen, and M. Osaki. 2005. The beneficial effect of aluminum and the role of citrate in Al accumulation in Melastoma malabathricum. New Phytol. 165:773780 .

Yang, C.Y., X.M. Liu, Z.Y. Chen, Y.S. Lin, and S.Y. Wang. 2016. Comparison of oil content and fatty acid profile of ten new Camellia oleifera cultivars. J. Lipids 2016:3982486.

Yu, H.N., P. Liu, Z.Y. Wang, W.R. Chen, and G.D. $\mathrm{Xu}$. 2011. The effect of aluminum treatments on the root growth and cell ultrastructure of two soybean genotypes. Crop Prot. 30:323328 .

Zakir Hossain, A.K., H. Koyama, and T. Hara. 2006. Growth and cell wall properties of two wheat cultivars differing in their sensitivity to aluminum stress. J. Plant Physiol. 163:3947.

Zeng, Q.L., R.F. Chen, X.Q. Zhao, H.Y. Wang, and R.F. Shen. 2011. Aluminum uptake and accumulation in the hyperaccumulator Camellia oleifera Abel. Pedosphere 21(3):358-364.

Zhang, H. and B. Raun. 2006. Oklahoma soil fertility handbook. 6th ed. Oklahoma State University, Stillwater, OK. 